\title{
EFFECT OF GAMMA RADIATION ON THE STRUCTURE AND THERMAL PROPERTIES OF POLYANILINE-COBALT/POLYCARBONATE NANOCOMPOSITE
}

\author{
R.M. Samy ${ }^{1 *}$, S.F. Hassan ${ }^{1}$, M.G. El-Feky ${ }^{1}$, T.M. Hegazy ${ }^{2}$, A.A. El-Hagg ${ }^{3}$ \\ 1 Nuclear Material Authority, El-maadi, Cairo, Egypt. \\ 2 Physics Department, Faculty of Girls, Ain Shams University, Cairo, Egypt. \\ 3 Physics Department, Faculty of Science, Al-Azhar University, (Girls), Egypt. \\ *Corresponding Authors: Rmshasan@gmail.com
}

\begin{abstract}
The induced alterations in the structure and thermal properties of polyaniline-cobalt/polycarbonate, PANI$\mathrm{Co} / \mathrm{PC}$, nanocomposite (NCP) owing to $\gamma$ irradiation have been investigated. The chemical composition and morphology of the prepared NCP samples were studied using scanning electron microscopy and energy dispersive spectrometry technique. Additionally, X-ray diffraction (XRD), FTIR spectroscopy, thermogravimetric analysis (TGA) and differential thermal analysis (DTA) were performed to investigate the resulted effect of $\gamma$ radiation. The $\gamma$ radiation with doses 50-350 kGy leads to the prevalence of intermolecular crosslinking which enhances the disordered phase and increases the bonds between the hydrogen of the PANI amine groups and carbonyl groups of PC. This is reflected in a rise in the degradation temperature values from 400 to $475^{\circ} \mathrm{C}$ indicating an improvement in the thermostability of the NCP samples. Additionally, the melting temperature increased from 350 to $361{ }^{\circ} \mathrm{C}$ indicating a more compact structure of the NCP samples.
\end{abstract}

Keywords: $\gamma$ radiation, Nanocomposite, XRD, FTIR spectroscopy, TGA, DTA

\section{INTRODUCTION}

Polymer nanocomposites (NCPs) that include inorganic nanoparticles (NPs) in its matrix attain desirable combined characteristics $[1,2]$. The physical properties of these NCPs are altered by varying the percentage of the organic and inorganic constitutes [3]. This modifies the properties of the resulting NCP and allows it to be suitable candidate for different applications [4]. Polyaniline (PANI) is a talented polymer due to its remarkable properties and stability [5]. It is useful in electrical and microelectronic fields [6].

Cobalt nanocrystal got more consideration than $\mathrm{Fe}$ and $\mathrm{Ni}$ owing to its distinguished characteristics and oxidation-resistance. Cobalt NPs are used in several applications such as catalyst for the Fischer-Tropsch reaction, as coatings and for electroplating [7]. Further, cobalt has two crystal phases: hexagonal closepacked and face-centered cubic. Lately, a new metastable $\varepsilon$-phase cobalt that is less dense than the other two phases was discovered by Dinge and Banwendi [8]. This structure is cubic (space group P4 1 32) with a unit cell parameter $a=6.097$. These allow cobalt-based
NPs to be extremely attractive and being efficient NPs [9]. Thus, NCPs based on cobalt have got more attention owing to the significant change in thermal [10], mechanical [11], electrical [12] and magnetic [13] properties relative to the pure organic polymers. On the other hand, Polycarbonates (PC) have significant characteristics such as good toughness, inflexibility and being thermally stable [14]. PC is an appropriate matter for hosting metal NPs owing to its unique properties. The inclusion of metal NPS into the PC matrix has a benefit because the merged matter joins properties from both the organic and inorganic materials [15-19].

The mass fraction of the amorphous portion in the semicrystalline polymers represents an essential task in characterizing the material. Also, the study of thermal characterization of polymers has become extensive. Some polymers have various attractive characteristics that permit it to be one of the most significant polymers. But in spite of its huge technological and financial importance, it still has a lot of problems associated with variation in its physical properties. One of these problems is its poor thermostability owing to the structure 
defects created throughout the polymerization route. Therefore, the stabilization of these polymers using irradiation is required [20]. The $\gamma$ irradiation creates free radicals via degradation, and then forms covalent bonds via crosslinking. This influences the polymer macromolecular construction and its morphology without changing its composition [21]. The bonds that are broken during degradation can be recognized by FTIR analysis of the blank and exposed samples. The current study aims to enhance the structural and thermal properties of PANI-Co/PC NCP using $\gamma$ radiation, so that the resultant $\mathrm{NCP}$ can be used in different applications.

\section{METHODOLOGY}

\subsection{Materials}

Aniline monomer, dodecyl benzene sulfonic acid (DBSA, surfactant), Cobalt chloride were obtained from Sigma-Aldrich Company, USA. PC was obtained from Sigma-Aldrich $\mathrm{GmbH}$, Cairo, Egypt.

\subsection{Preparation of PANI}

A stable polyaniline-dodecylbenzenesulfonic acid (PANI-DBSA) colloidal dispersion was prepared as previously published [22] as follows: aniline monomer and dodecyl benzene sulfonic acid (DBSA) of ratio (3:1) in $75 \mathrm{ml}$ water/isopropanol (IPA) mixture (3:1) have been homogenized for $10 \mathrm{~min}$ to form the miniemulsion. Then, $25 \mathrm{ml}$ of ammonium peroxydisulfate (APS) solution (1 wt.\%) was added drop-wisely to the former miniemulsion. Polymerization was performed, at room temperature, with strong stirring at $10,000 \mathrm{rpm}$ for $15 \mathrm{~min}$. The color was changed from white anilinium-DBSA complex in water to blue, then turned into dark green. Finally, a green and very stable PANI-DBSA dispersion was obtained. The colloid dispersal is centrifuged, washed by water/methanol mix for several times and then dried in an electric oven for 4 hrs at $70^{\circ} \mathrm{C}$ and kept for further use.

\subsection{Preparation of PANI-Co NCP}

The polymerization reaction has been done; where aniline monomer and DBSA of ratio (3:1) was homogenized by high shearing affect homogenizer at $10,000 \mathrm{rpm}$ in existence of DBSA to form the miniemulsion. A $20 \mathrm{ml}$ of $0.25 \%$ cobalt chloride solution has been added to the formed miniemulsion with continuous strong stirring at $10,000 \mathrm{rpm}$ till a green colloidal dispersion of PANI/Co NCP is obtained. The produced green colloidal dispersion was then centrifuged, washed several time by water/methanol mix, filtered and dried at $70{ }^{\circ} \mathrm{C}$ for $4 \mathrm{~h} \mathrm{[22].}$

\subsection{Preparation of PANI-Co/PC NCP}

Three grams of PC powder were dropwisely added to $50 \mathrm{ml}$ of DMF with a continuous vigorous stirring till all $\mathrm{PC}$ powder liquefies. Then $0.125 \mathrm{~g}$ of the prepared PANI/Co was added to the preceding solution under stirring at room temperature until a homogeneous colored solution is obtained. The obtained solution was then casted onto clean Petri dish and left to dry at $50^{\circ} \mathrm{C}$ for 24 hours.

\subsection{Irradiation facilities}

The PANI-Co/PC NCP samples were exposed to $\gamma$ radiation with doses $50-350 \mathrm{kGy}$ with ${ }^{60} \mathrm{Co}$ source (Canada A.E.A Ltd.) with energy range of 1.173-1.332 $\mathrm{MeV}$ at 2.4 Gy/min (A,E.A., NCRRT, Egypt).

\subsection{Instrumentation}

The chemical composition of the PANI$\mathrm{Co} / \mathrm{PC}$ NCP samples was examined by energy dispersive spectrometry (EDS) using scanning electron microscope (JEOL, JSM-5910LV)

The X-ray diffraction (XRD) was conducted using Shimadzu 6000 . The $X$ ray diffractometer was operational with $\mathrm{Cu}-\mathrm{k}_{\alpha}$ ray of $\lambda=1.5406 \AA$ and scan speed of $2 \%$ min.

FTIR Spectroscopy was performed with a spectrophotometer (Shimadzu, 8201 PC, with an accuracy $\pm 4 \mathrm{~cm}^{-1}$ ).

The thermal behavior of the PANI-Co/PC NCP was illustrated applying DTA and TGA Shimadzu-50. For DTA measurements we used a reference material $\left(\alpha-\mathrm{Al}_{2} \mathrm{O}_{3}\right.$ powder $)$. The measurements were performed at $10^{\circ} \mathrm{C} / \mathrm{min}$ with nitrogen gas flow rate $20 \mathrm{~cm}^{3} / \mathrm{min}$.

\section{RESULTS AND DISCUSSION}

\subsection{SEM Analysis for PANI-Co and PANI- Co/PC NCPs}

Fig. 1a shows the SEM micrograph of the synthesized PANI-Co NCP. The Co NPs are formed in the form of clusters or colonies. The 
formed NPs are of size in the $44-63 \mathrm{~nm}$. It can be concluded that the formed NPs are in the range of nanosize and represented as bright spots or zones which are quite embedded into the darker zones of polyaniline matrix.

Fig. 1b shows SEM micrographs of the PANI-Co/PC NCP. It is shown that the $\mathrm{PANI} / \mathrm{Co}$ is well dispersed and compatible with the PC matrix. The bright spots are for the $\mathrm{CO}$ NPs.

Fig. 1c shows the energy dispersive spectrometry image revealing the compositional analysis for PANI-Co NCP. The elements are with percentages near nominal values (Table 1).
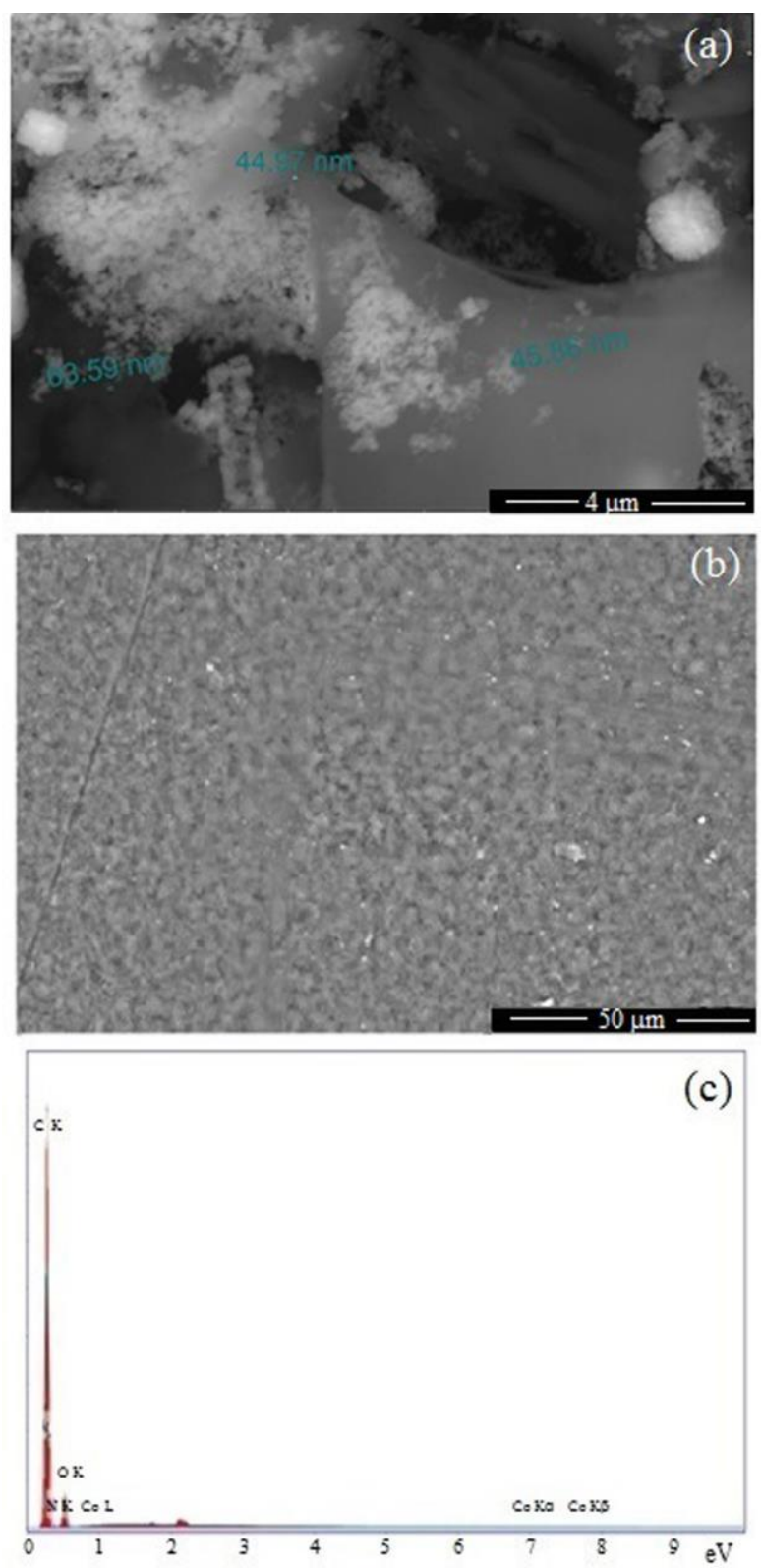

Fig. 1 SEM micrograph of the prepared (a) PANI-Co, (b) PANI-Co/PC NCPs and(c) Energy dispersive spectrometry image of the blank PANI-Co/PC NCP.

Table 1. The chemical composition of the Pani-Co/PC NCP samples

\begin{tabular}{ccccc}
\hline Element & Weight $\%$ & Atomic $\%$ & Net Int. & Error \% \\
\hline C K & 76.14 & 80.79 & 1018.38 & 3.79 \\
N K & 3.19 & 2.90 & 4.20 & 31.26 \\
O K & 20.41 & 16.26 & 100.54 & 12.09 \\
CoK & 0.16 & 0.03 & 1.96 & 64.13 \\
\hline
\end{tabular}




\section{2 $\mathrm{X}$ ray diffraction}

Actually, polymers are semicrystalline containing a mixture of ordered and amorphous phases. The disordered portion in the semicrystalline polymers is responsible for evaluating the performance of the NCP. XRD was conducted on the blank and exposed NCP samples. Fig. 2 shows the XRD patterns of the pristine and exposed PANI-Co/PC NCP samples measured in the $2 \theta$ range $10-60^{\circ}$. The XRD data showed a wide peak centered at $18^{\circ}$, representing the partial crystalline structure of NCP. This wide peak is due to the amorphous PANI as the amorphous PANI has two wide peaks at $2 \theta=20.4^{\circ}$ and $24.8^{\circ}$. These peaks are owing to the periodicity parallel and perpendicular to PANI chains, correspondingly [23]. No peaks appeared for Co indicating the incorporation of Co in the NCP matrix. There is slight change in the position of the wide peak after the NCP samples were exposed to $\gamma$; indicating that the lattice parameters were broken 「241.

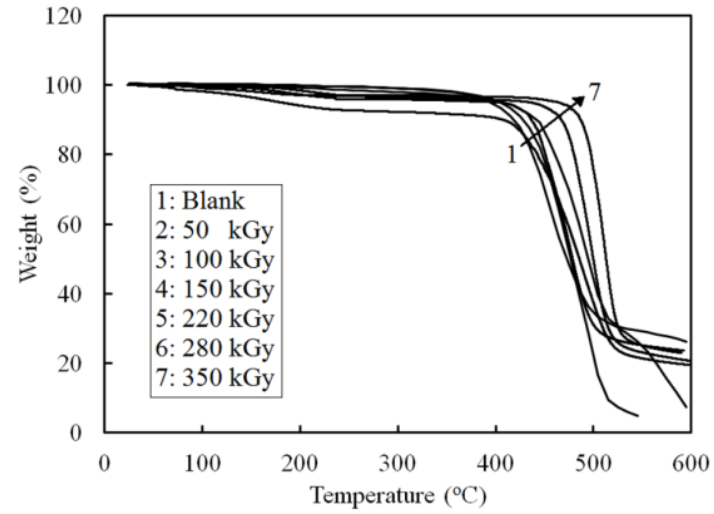

Fig. 2 XRD curves of the exposed PANI-Co/PC NCP samples and the blank.

Lorentz fitting was applied on the diffraction pattern of the peak (centered at $18^{\circ}$ ) for all NCP samples. Therefore the area under the wide peak, which is the integral intensity I, was computed; then plotted in Fig. 3a versus $\gamma$ dose. The intensity decreased in magnitude on raising the $\gamma$ doses to $350 \mathrm{kGy}$, indicating higher amorphous nature. This can be owing to the action of $\gamma$ ray that enhances the bonding between the $\mathrm{H}$ of PANI amine groups and the carbonyl groups of PC through crosslinking. This reduces the ordered portion and turns it into non-arranged ones. These results can be interpreted based on the fact that the amine and imine groups involved in the PANI macromolecules contribute to intermolecular reactions that create several hydrogen bonds among adjacent chains. The amine groups of PANI form hydrogen bonds with carbonyl groups of $\mathrm{PC}$ which increases through the crosslinking created by $\gamma$ irradiation. Additional factor that enhances the crosslinking is the presence Co NPs that encourage the charge transfer process due to the shift of charge density between molecular orbital's (MO) of Co NPs and those of PANI which are ligand in character [25]. In our previous work, we got similar trend for the exposed $\mathrm{PC} / \mathrm{SnS}_{2} \mathrm{NCP}$ [26]. The exposure of PC-SnS $\mathrm{S}_{2} \mathrm{NCP}$ led to the domination of crosslinking that improved the disorder character in the NCP, thus enhanced its resilience and compactness.

The values of crystallite size $\mathrm{L}$ were computed applying Scherrer equation:

$\mathrm{L}=(0.89 \lambda) /(\Delta \mathrm{W} \cos \theta)$

where $\Delta \mathrm{W}$ is the peak's halo's width at half maximum intensity. $\lambda$ is wavelength of the $\mathrm{X}$ rays used $\left(1.54 \mathrm{~A}^{\circ}\right)$, and $\theta$ is the angle. The crystallite size decreases on raising the $\gamma$ dose up to $350 \mathrm{kGy}$ (Fig. 3b). The decrease in the L values can be owing to the creation of free radicals, chain scission, and crosslinking of the polymeric NCP chains upon irradiation [24].
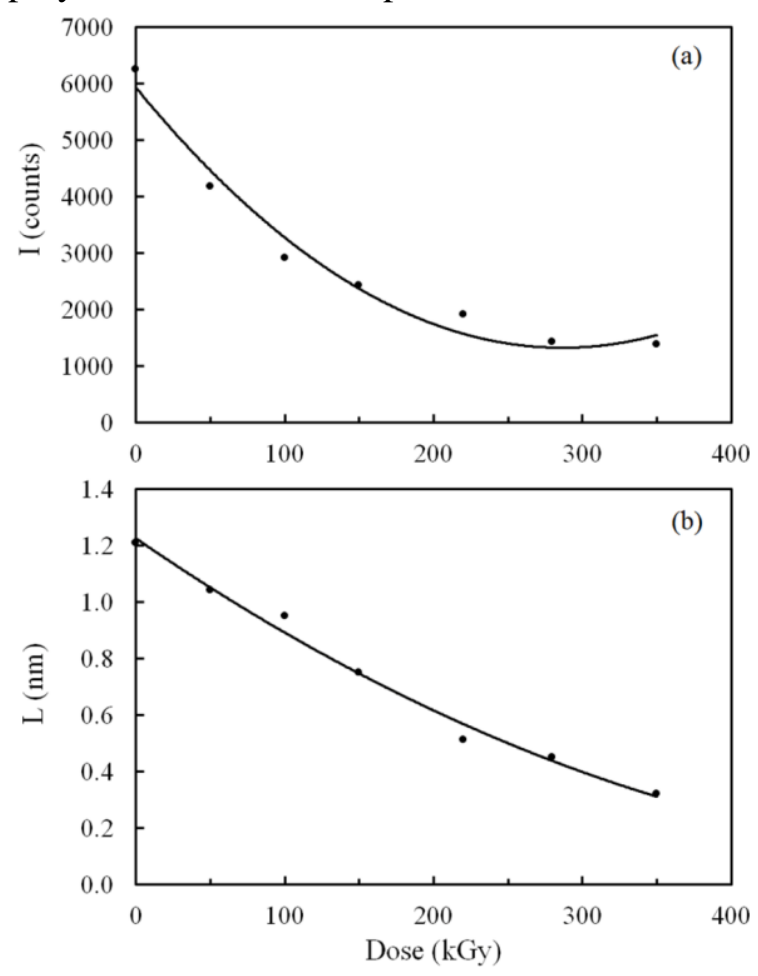

Fig. 3 Dependence of the (a) integral intensity I and (b) crystallite size $\mathrm{L}$ on the $\gamma$ dose. 


\subsection{FTIR Spectra Analysis}

FTIR spectroscopy has been carried out (in the absorbance manner) to explore the structural modifications of the PANI-Co/PC NCP due to $\gamma$ irradiation. Fig. 4 shows the FTIR absorbance bands for the blank and some exposed NCP samples. The modifications have been predicted considering the variations in the intensity of the peak and any available wave number shift accompanied with the function groups identifying the NCP samples. The modes of chemical bonds in FTIR spectra are characterized according to Noda et al. [27]. The NCP samples exhibit characteristic vibrations at $830 \mathrm{~cm}^{-1}$ (Para out-of-plane aromatic $\mathrm{CH}$ wag, two adjacent $\mathrm{Hs}$ ), $1013 \mathrm{~cm}^{-1}$ (Para inplane aromatic $\mathrm{CH}$ bend), $1140 \mathrm{~cm}^{-1}$ (C-O-C), $1165 \mathrm{~cm}^{-1}$ (Carbonate $\mathrm{C}-\mathrm{O}$ stretch), $1405 \mathrm{~cm}^{-1}$ (Para aromatic ring semicircle stretch), 1481 $\mathrm{cm}^{-1}$ (stretching mode of vibration for benzenoid unit of PANI) [9], $1605 \mathrm{~cm}^{-1}$ (Para aromatic ring quadrant stretch), $1775 \mathrm{~cm}^{-1}$ $(\mathrm{C}=\mathrm{O}$ stretch $), 2875 \mathrm{~cm}^{-1},\left(\mathrm{CH}_{3}\right.$ symmetric stretch), $2980 \mathrm{~cm}^{-1}\left(\mathrm{CH}_{3}\right.$ asymmetric stretch), $3056 \mathrm{~cm}^{-1}$ (aromatic $\mathrm{CH}$ stretches) and 3533 $\mathrm{cm}^{-1}$ (OH group). It is noticed that some absorption bands in the NCP samples were shifted towards higher wavenumbers than the pure PC polymer. For example, the peaks that should appear at 1160, 1600 and $2970 \mathrm{~cm}^{-1}$ actually appeared at 1165, 1605 and $2980 \mathrm{~cm}^{-1}$,
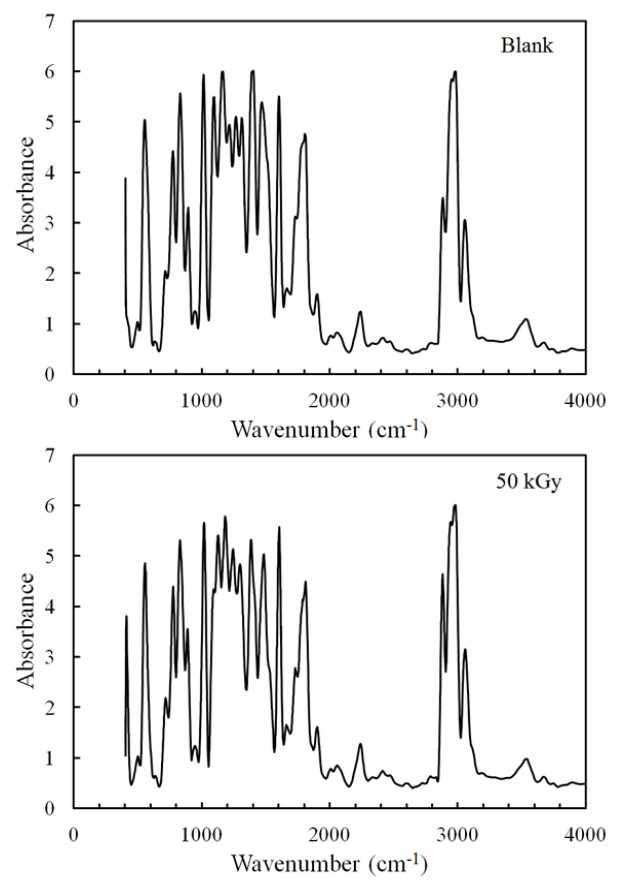

respectively. This can be owing to the incorporation of the PANI-Co into the PC matrix. All the peaks exhibited variation in intensity with slight shift in wavenumber with the $\gamma$ dose. The two benzene rings of PC could be recognized in the NCP samples since the appearance of the bands correlated to $\mathrm{C}-\mathrm{H}$ aromatic stretching $\left(3056 \mathrm{~cm}^{-1}\right)$ and $\mathrm{CH}_{3}$ symmetric stretch $\left(2875 \mathrm{~cm}^{-1}\right)$ that incresed with raising dose to $350 \mathrm{kGy}$ [21]. Additionally, the weak band around $3533 \mathrm{~cm}^{-1}$ in the blank NCP demonstrated the limitation of the terminal $\mathrm{OH}$ group indicating higher molecular weight [28]. On $\gamma$ irradiation up to $350 \mathrm{kGy}$, it decreases meaning the predominance of crosslinking. This can be explained based on that the preparation of PC requires transesterification of diphenyl carbonate with bisphenol A with removal of phenol. Thus the primary composition of $\mathrm{OH}$ group will decrease with increasing the chain length [28]. The $(\mathrm{C}=\mathrm{O})$ group at $1778 \mathrm{~cm}^{-1}$ that appeared in the spectrum of the PC doped with PANI-Co is similar to that in the case of blank PC [29]; possibly owing to the overlapping between bands of PC and PANI-Co. The relatively slight shifts of the bands mentioned above means an exact reaction of PANI-Co with PC concerning the bonding between hydrogen of $\mathrm{C}=\mathrm{O}$ of $\mathrm{PC}$ and amine groups of PANI in the NCP [29]. Moreover, this reaction can also affect the morphology of the NCP.
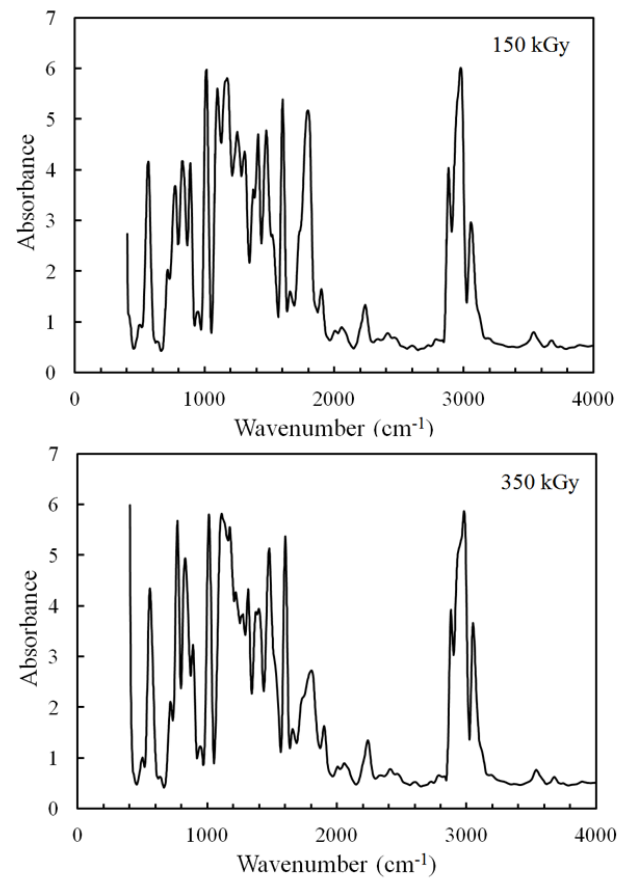

Fig. 4 FTIR absorbance spectra of some exposed PANI-Co/PC NCP samples and the blank. 


\subsection{Thermogravimetric analysis (TGA)}

TGA was conducted on the PANI-Co/PC $\mathrm{NCP}$ to determine the modification in thermostability induced in the NCP samples due to $\gamma$ dose. TGA was carried out up to 600 ${ }^{\circ} \mathrm{C}$, at $10^{\circ} \mathrm{C} / \mathrm{min}$. The TGA thermograms of the exposed NCP samples as well as the blank are shown in Fig. 5. It is seen that the NCP samples decompose in one main weight loss stage. TGA curves indicated that the degradation temperature $T_{0}$, means the temperature at which the decomposition starts, changes significantly with the $\gamma$ dose. Fig. 6 a shows the dependence of $T_{0}$ on the $\gamma$ dose. The onset temperature of decomposition shows a decrease around the 50 $\mathrm{kGy}$ exposed sample owing to initial chain scission; then increases on raising the dose to $350 \mathrm{kGy}$ owing to crosslinkig. This can be explained based on the fact that the $\mathrm{PC}$ in the $\mathrm{PANI}-\mathrm{Co} / \mathrm{PC}$ is thermally stable and degrades at temperatures higher than $300{ }^{\circ} \mathrm{C}$ [30]. Additionally, PANI is also thermally stable and its backbone does not degrade even up to 400 ${ }^{\circ} \mathrm{C}$ [30]. Therefore, thermostability of NCP can be affected by the thermostability of both PC and PANI. The $\gamma$ radiation increases the compact structure of the NCP samples via crosslinking. In addition, the existence of Co NPs affects strongly the thermostability of the NCP.

\section{Activation energy of thermal decomposition $\left(\boldsymbol{E}_{a}\right)$}

$E_{a}$ is computed to obtain information concerning thermostability of the NCP samples. The technique projected by Horowitz and Metzger [31] has been used to compute $\mathrm{E}_{\mathrm{a}}$ for the PVA-PEG/Co $\mathrm{CO}_{4} \mathrm{NCP}$. Fig. $6 \mathrm{~b}$ shows that $E_{a}$ increases with increasing the $\gamma$ dose up to $350 \mathrm{kGy}$. The increase in $\mathrm{E}_{\mathrm{a}}$ can be due to the homogenous incorporation of PANI-Co in the PC matrix through crosslinking [21].

\subsection{Differential thermal analysis (DTA)}

DTA technique was measured up to $400{ }^{\circ} \mathrm{C}$ at $10{ }^{\circ} \mathrm{C} / \mathrm{min}$. The thermo-grams of the blank $\mathrm{PANI}-\mathrm{Co} / \mathrm{PC}$ and exposed samples showed an endothermic peak owing to the melting temperature $\left(\mathrm{T}_{\mathrm{m}}\right)$. Fig. 7a shows the DTA thermogram, illustrating $\mathrm{T}_{\mathrm{m}}$. It is seen that the samples were characterized by a range of poorly specific melting temperatures. This is owing to the degree of freedom of the polymeric chains and the variety in chain length.

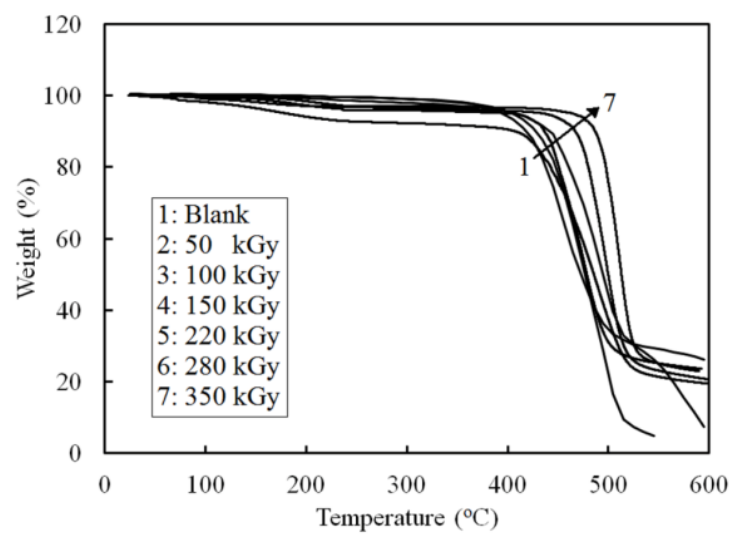

Fig. 5 TGA thermograms of the exposed PANI$\mathrm{Co} / \mathrm{PC}$ NCP samples and the blank.
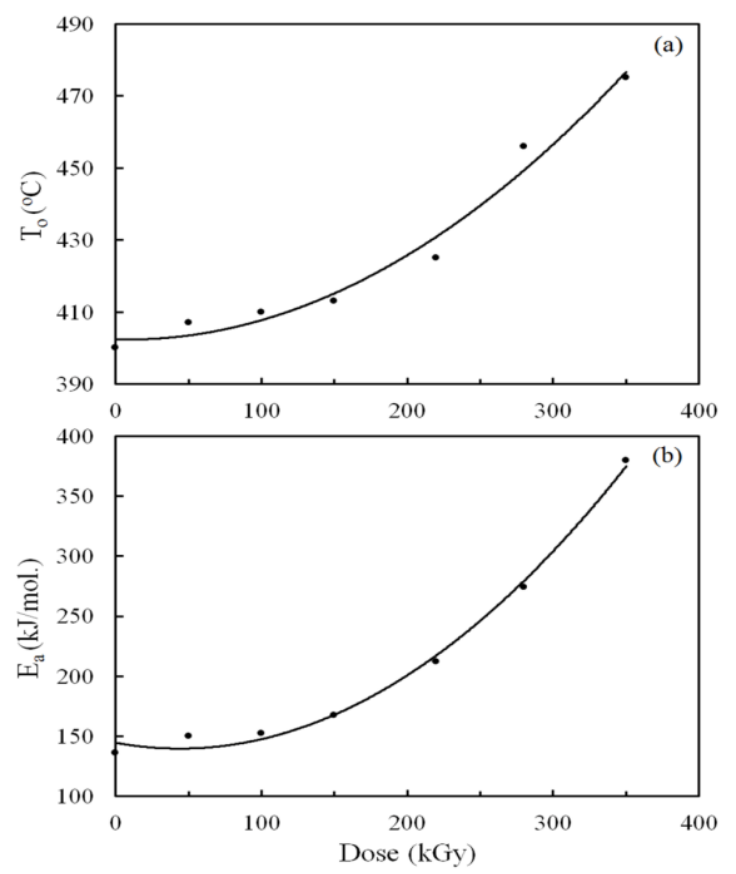

Fig. 6. Dependence of the (a) onset temperature of decomposition $T_{o}$ and (b) activation energy of thermal decomposition $\mathrm{E}_{\mathrm{a}}$ on the $\gamma$ dose.

The values of $T_{m}$ were calculated and represented in Fig. $7 \mathrm{~b}$ versus $\gamma$-dose. $\mathrm{T}_{\mathrm{m}}$ increased on raising the $\gamma$ dose to $350 \mathrm{kGy}$ owing to $\mathrm{u}$ the crosslinking that reduces the ordered phase thus increasing the disorder character. Alternatively, the shorter chains in the NCP have better mobility; consequently allow molecules to be reoriented forming ordered segment. This is similar to the cage effect that includes the free radical re- 
combination prior to taking part in reactions that encourage crosslinking [32, 33]. Through crosslinking, the chains can be joined end to end; the increase of the polymeric chain length add also to the shift of $\mathrm{T}_{\mathrm{m}}$ toward higher temperatures [23].
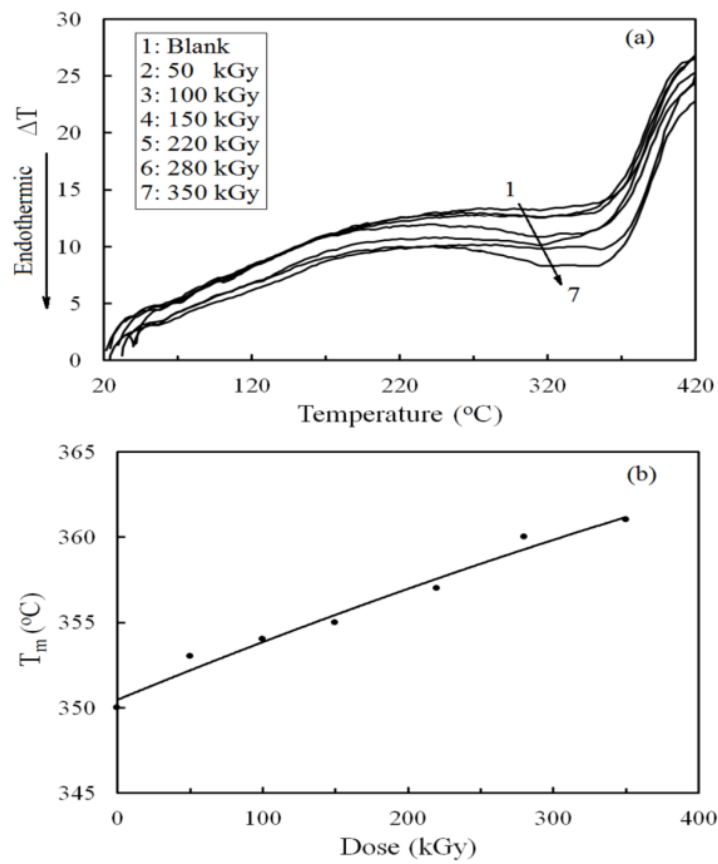

Fig. 7 (a) DTA thermograms of the exposed PANI-Co/PC NCP samples and the blank, (b) Variation of the melting temperature $\mathrm{T}_{\mathrm{m}}$ with

\section{CONCLUSION} the $\gamma$ dose.

The $\gamma$ irradiation of PANI-Co/PC NCP causes the domination of crosslinking, modifying its structural and thermal properties. The $\gamma$ doses up to $350 \mathrm{kGy}$ led to increasing the disorder character in the NCP, thus enhancing its resilience and compactness. This could be drawn from the decrease in both integral intensity and crystallite size. Additionally, the $\gamma$ radiation encourages the creation of hydrogen bonding between the amine groups of PANI and the $\mathrm{C}=\mathrm{O}$ of $\mathrm{PC}$ through crosslinking. This enhances the thermostability of the NCP samples, with an increase in activation energy of thermal decomposition and melting temperature.

\section{REFERENCES}

[1] Ehsani, A.; Bigdeloo, M.; Ansari, M.Y.; Mirtamizdoust, B.; Heidari, A.A.; Hadi, M.; Shiri, H.M. Nanocomposite of Conjugated Polymer/Nano-Flowers Cu(II) Metal-Organic
System with 2-Methylpyridinecarboxaldehyde Isonicotinohydrazide as a Novel and Hybrid Electrode Material for Highly Capacitive Pseudocapacitors. Bull. Chem. Soc. Jpn., 2018, 91(4), 617-622

[2] Zhao, G.; Huang, X.; Tang, Z.; Huang, Q.; Niu, F.; Wang, X. Polymer-based nanocomposites for heavy metal ions removal from aqueous solution. Polym. Chem., 2018, 9, 3562-3582

[3] Botsi, S.; Tsamis, C.; Chatzichristidi, M.; Papageorgiou, G.; Makarona, E. Nano-Struct. Facile and cost-efficient development of PMMA-based nanocomposites with custommade hydrothermally-synthesized znO nanofillers. Nano-Struct. Nano-Objects., 2019. $17,7-20$

[4] Huang, X.; Wang, R.; Jiao, T.; Zou, G.; Zhan, F.; Yin, J.; Zhang, L.; Zhou, J.; Peng, Q. Facile preparation of hierarchical AgNp-loaded mxene/ $/ \mathrm{Fe}_{3} \mathrm{O}_{4} /$ polymer nanocomposites by electrospinning with enhanced catalytic performance for wastewater treatment. ACS Omega., 2019, 4, 1897-1906

[5] Shukla, V.K.; Yadav, P.; Yadav, R.S.; Mishra, P.; Pandey, A.C. A new class of PANI-Ag core-shell nanorods with sensing dimensions. Nanoscales, 2012, 4 (13), 3886-3893

[6] Reda, S.M.; Al-Ghannam, S.M. Synthesis and Electrical Properties of Polyaniline Composite with Silver Nanoparticles. Advances in Materials Physics and Chemistry, 2012, 2, 7581.

[7] Zhang, Z.; Zhou, T.; Lu,M.; Poh, A.W.C.; Piramanayagam. S.N. Cobalt Nanomaterials: Synthesis and Characterization. 2011, https:/ /doi.org/10.1002/9783527610419.ntls0178

[8] Dinega, D.P.; Bawendi , M.G. A solution phase chemical approach to a new crystal structure of cobalt. Angew. Chem. Int. Ed. Engl., 1999, 38(12 ), 1788-1791

[9] Bedre, M.D.; Deshpande, R.; Salimath, B., Abbaraju, V. Preparation and Characterization of Polyaniline-Co3O4 Nanocomposites via Interfacial Polymerization, American Journal of Materials Science, 2012, 2(3), 39-43

[10] Zanetti, M.; Lomakin, S.; Camino, G. Polymer layered silicate nanocomposites. Macromol. Mater. Eng., 2000, 279, 1-9

[11] Mallikarjun, N.N.; Manohar, S.K.; Kulkarni, P.V.; Venkata-raman, A.; Aminabhavi, T. M. Novel high dielectric constant nanocomposites of polyanaline dispersed with $\gamma-\mathrm{Fe}_{2} \mathrm{O}_{3}$ nanoparticals. J. Appl. Polym. Sci., 2005, 97, 1868-1874

[12] Bedre, M.D.; Basavaraja S.; Deshpande, R.; Balaji, D.S; Venkataraman. A. Preparation and 
Characteriza-tion of Polypyrrole Silver Nanocomposites via Interfacial Polymerization. Inter. J. Polym. Mater., 2010, 59, 531-543

[13] Godovski, D.Y. Electron behavior and magnetic properties of polymer nanocomposites. Adv. Polym. Sci., 1995, 119, 79-122

[14] Nouh, S.A.; Benthami, K.; Samy, R.M.; ElHagg, A.A. Effect of gamma irradiation on the structure and optical properties of PC-PBT/Ag polymer nanocomposites films. Chem. Phys. Lett., 2020, 741, 137123, https://doi.org/10.1016/j.cplett.2020.137123

[15] Khanna, P.K.; Singh, N.; Charan, S.; Subbarao, V.; Gokhale, R.; Mulik, U.P. Synthesis and characterization of Ag/PVA nanocomposite by chemical reduction method. Mater. Chem. Phys., 2005, 93, 117-121

[16] Mbhele, Z.H.; Salemane, M.G., van Sittert, C.G.C.E.; Nedeljković, J.M.; Djoković, V.; Luyt, A.S. Fabrication and characterization of Silver-polyvinyl alcohol nanocomposites. Chem. Mater., 2003, 15, 5019-5024

[17] Zeng, R., Rong, M.Z., Zhang, M.Q., Liang, H.C., Zeng, H.M. Laser ablation of polymerbased silver nanocomposites. Appl. Surf. Sci., 2002, 187, 239-247

[18] Zhang, Z.; Han, M.J. One-step preparation of size-selected and well-dispersed silver nanocrystals in polyarylonitrile by simultaneous reduction and polymerization. $\mathrm{J}$. Mater. Chem., 2003, 13, 641-643

[19] Firth, A.V.; Haggata, S.W.; Khanna, P.K.; Williams, S.J.; Allen, J.W.; Magennis, S.W.; Samuel, I.D.; Cole- Hamilton, D.J. Production and luminescent properties of cdse and cds nanoparticle-polymer composites. J. Lumin., 2004, 109, 163-172

[20] Abdel-Naby, A.S.; Nouh, S.A. Stabilization of poly (vinyl chloride) against laser radiation with ethyl-N-phenylmaleimide-4-carboxylate. Polym. Degrad. Stab., 2002, 76, 419-423

[21] Nouh, S.A.; Radwan, Y.E.; Elfiky, D.; Abutalib, M.M.; Bahareth, R.A.; Hegazy, T.M.; Fouad, S.S. Structure, thermal, optical and electrical investigation of the effect of heavy highly energetic ions irradiations in Bayfol DPF 5023 Nuclear Track Detector. Radiat. Phys. Chem., 2014, 97, 68-74

[22] Elhalawany, N.; Saleeb, M.M.; Zahran, M.K. New synthesis type route for preparation of some highly conductive polyaniline nanocomposites of core-shell structures. J. Mater. Sci.-Mater. Electron., 2017, 28, 1817318182

[23] Alhazime, A.A.; Benthami, K.A; Alsobhi, B.O.; Ali, G.W.; Nouh, S.A. Pani-Ag/PVA nanocomposite: Gamma induced changes in the thermal and optical characteristic. J. Vinyl. Addit. Technol., 2020, DOI: 10.1002/vnl.21782

[24] Gupta, S.K.; Singh, P.; Kumar, R., Kumar, S. Gamma radiation induced modifications on physicochemical properties of Makrofol (KG and N) polycarbonate. Adv. Polym. Technol., 2015, 34, 21510(1-6)

[25] Elhalawany, N.; Saleeb, M.M.; Zahran, M.K. New synthesis type route for preparation of some highly conductive polyaniline nanocomposites of core-shell structures. J Mater Sci: Mater Electron, 2017, 28, 1817318182

[26] Nouh, S.A.; Barakat, M.ME.; Ali, G.W.; ElShamy, N.T.; Benthami, K.; Alhazime, A.A. Gamma radiation induced modifications in PC/SnS nanocomposite: structural and optical studies. Radiat. Eff. Defects Soilds, 2020, https://doi.org/10.1080/10420150.2020.178059 5

[27] Noda, I.; Dowrey, A.W.; Marcott, C.; In Physical properties of polymers, in: J.E. Mark (Ed.), Handbook, AIP Press, New York, 1996.

[28] Srivastava, A.; Singh, T.V.; Mule, S.; Rajan, C.R.; Ponrathnam, S. Study of chemical, optical and thermal modifications induced by $100 \mathrm{MeV}$ silicon ions in a polycarbonate film. Nucl. Instrum. Meth., 2002, 192, 402-406

[29] Ogurtsov, N.A.; Noskov, Y.V.; Fatyeyeva, K.Y.; Ilyin, V.G.; Dudarenko, G.V.; Pud, A.A. Deep impact of the template on molecular weight, structure, and oxidation state of the formed polyaniline. J. Phys. Chem. B, 2013 , 117(17), 5306-5314

[30] Noskov, Y.; Mikhaylov, S.; Coddeville, P.; Wojkiewicz, JL.; Pud, A. Acid-dopant effects in the formation and properties of polycarbonate-polyaniline composites. Synthetic Metals., 2016, 217, 266-275

[31] Horowitz, H.H.; Metzger, G. A new analysis of thermogravimetric traces. Anal. Chem., 1963, 35 1464-1468

[32] Reddy, K.R.; Karthik, K.V.; Prasad, S.B.; Soni, S.K.; Jeong, H.M.; Raghu, A.V. Enhanced photocatalytic activity of nanostructured titanium dioxide/polyaniline hybrid photocatalysts. Polyhedron, 2016, 120, 169-174

[33] Hanifehpour, Y.; Hamnabard, N.; Mirtamizdoust, B.; Joo, S.W. Sonochemical Synthesis, Characterization and Sonocatalytic Performance of Terbium-Doped CdS Nanoparticles. J. Inorg. Organomet. Polym., 2016, 26, 623-631 
تأثير أشعة جاما علي الخواص التركيبية و الحرارية للمركب النانوي بولي انيلين - كوبلت/ بوليكربونات

رانيا محمد سامي1 ، سيد فهمي حسن1 ، محمد جلال الفقي1 ،

طارق محمد الدسوقي2 ، عزة عبد الرؤوف عبد القادر3

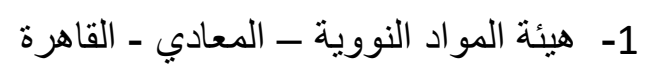

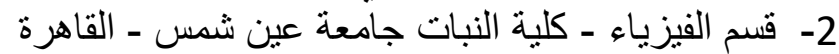

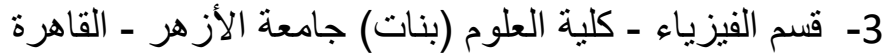

الملخص العربي

تم در اسة التغير ات في الخو اص التركيبية والحر ارية الناتجة عن التشعيع الجـامي للمركب النـانوي البولي انيلين- كوبلت/ بوليكربونات. و تـم در اسـة التركيب الكيميـائي للعينـات المحضـرة باستخدام الماسـح الإكترونـي ومطياف تشتت الطاقـة. بالإضـافة إلي دراسـة حيـود الاشـعة السينية (XRD) ومطيـاف الاشـعة تحـت الحمـر اء و التحليل الوزني الحر اري (TGA) و التحليل الحراري التفاضـلي (DTA) وذللك لدر اسـة تـأثثر اثـعة جاما علي العينات. وقد وجد ان اشعة جاما في مدىى الجرعـات مـن 50 إلى 350 كيلـو جـراي يؤدي إلي زيـادة التنـابك (crosslinking) والذي يزيـد الـروابط بين الهيدروجين في البولي انبلين ومجموعـات الكربون في البوليكربونات ـ وقد انعكس هذا علي زيادة درجة حر ارة التحلل من 400 إلى 475 م مما يدل علي تحسين الثبات الحرارى للعينات المحضرة. وكذلك زيادة درجة حرارة الإنصهار من 350 إلى 361 درجة مئوية مما يشير إلي هيكل تركيبي اكثر صلابة و إحكام. 